\title{
DARI MATA TURUN KE TELINGA: PERAN CUES DALAM NAVIGASI KONTEN APLIKASI DIGITAL AUDIO STREAMING
}

\author{
Reno Dalu Maharso ${ }^{1}$, Irwansyah ${ }^{2}$ \\ 1,2Prodi Ilmu Komunikasi FISIP Universitas Indonesia \\ reno.dalu@gmail.com',dr.irwansyah.ma@gmail.com²
}

\begin{abstract}
Abstrak
Para pengguna ponsel pintar (smartphone users) sudah terbiasa menggunakan aplikasi mobile yang dipasangkan pada perangkat mereka. User mencari konten yang mereka inginkan dengan cara mengandalkan aspek visual yang disajikan oleh suatu aplikasi mobile. Aspek visual juga berlaku untuk menavigasi diri user dalam aplikasi yang menyediakan konten audio seperti aplikasi digital audio streaming. User mengandalkan aspek visual berupa cues pada Social Information Processing Theory (SIPT). Verbal cues antara lain nama penyanyi, judul lagu, nama playlist, lalu non-verbal cues seperti artwork yang menyertai sebuah konten lagu. Dengan mengambil contoh aplikasi Spotify, peneliti ingin menunjukkan bahwa aspek visual merupakan aspek utama dalam navigasi aplikasi konten audio. Penelitian dilakukan dengan analisis konten kualitatif untuk menelaah cues SIPT yang terdapat pada aspek navigability dalam model MAIN, diperkuat dengan focus group discussion kepada user Spotify untuk mendapatkan data mengenai pengalaman navigasi konten musik lewat cues yang tersedia. Analisis dilakukan dengan metode kualitatif deskriptif untuk menunjukkan aspek-aspek cues yang dominan. Hasil penelitian menunjukkan fitur search paling banyak digunakan untuk mencari konten lagu yang diinginkan dan user menavigasi pencarian terutama lewat judul lagu.
\end{abstract}

Kata Kunci: aplikasi mobile, cues, digital audio streaming, navigasi, visual

\begin{abstract}
Smartphone users have accustomed to using mobile applications - apps - on their phones, either pre-installed or obtained through the app market. Users look for any content they desire in an app by relying on visual aspects presented by the app itself. These visual aspects also relied on when users need to navigate themselves through audio content made available in digital audio streaming apps. These aspects in the framework of Social Information Processing Theory (SIPT) in terms of verbal cues are artists' names, song titles, playlists' names, and non-verbal cues are artworks that accompany audio contents. Taking Spotify as a sample case, writers want to show that visuals become the sole aspect to navigate through content in a digital audio streaming app. The writers use qualitative content analysis to study elements of SIPT cues in the MAIN model. A focus group discussion to Spotify users is also conducted to obtain data about their navigating experience through cues available in the app. The analysis was conducted qualitativedescriptively to show which dominant aspects of cues. Results show 'search' as the most used feature when navigating through Spotify, and song title becomes the most popular way to search for songs.
\end{abstract}

Keywords: cues, digital audio streaming, mobile app, navigation, visual 


\section{PENDAHULUAN}

Kehidupan manusia saat ini tidak terlepas dari musik. Kapan saja dan di mana saja manusia bisa mendengarkan musik dengan mudah. Hal ini menjadi mungkin karena perkembangan teknologi. Konsumsi musik secara massal ditandai dengan teknologi rekaman dan reproduksi musik yang tersedia bagi konsumen secara luas, mulai dari adanya fonograf, musik di radio, kehadiran musik di TV, kehadiran compact disc, hingga musik digital lewat iTunes (Straubhaar, LaRose, \& Davenport, 2012, p. 126). Di era mobile seperti sekarang, salah satu cara paling mudah bagi pendengar musik yang juga pengguna perangkat digital - user - untuk mendengarkan musik adalah melalui ponsel pintar dalam genggaman tangan mereka. Bahkan ponsel pintar menawarkan beberapa cara untuk mengakses musik seperti aplikasi pemutar musik, aplikasi video streaming, dan aplikasi digital audio streaming.

Istilah streaming, menurut Herbert, Lots, dan Marshall (2018) identik dengan sebuah proses transmisi konten media melalui jaringan internet secara real-time. Proses streaming berbeda dengan proses transmisi dengan cara mengunduh. Dalam proses streaming, sebuah file yang dikirim melalui internet dan diterima suatu perangkat dapat langsung direproduksi oleh perangkat penerima tersebut. Proses ini tidak memerlukan perangkat penerima menyimpan file pada media penyimpanannya (storage) sebagaimana yang diperlukan dalam proses mengunduh. Streaming memiliki karakteristik utama berupa akses on-demand tanpa putus ke suatu katalog konten. Katalog konten tersebut berukuran relatif besar, dan konektivitas dimungkinkan melalui jaringan internet (Herbert, Lotz, \& Marshall, 2018, pp. 3-4). Industri teknologi komunikasi yang berkembang pesat membentuk proses streaming sebagai layanan penyedia konten kepada user, baik menggunakan sistem berlangganan ataupun tidak dikenakan biaya (Herbert et al., 2018, p. 4).

Namun dari pemaparan di atas, perubahan terbesar sejak kemunculan dan adopsi streaming secara masif adalah pola konsumsi user dari konsumsi berdasarkan kepemilikan ke konsumsi berdasarkan akses yang dimiliki. User tidak perlu lagi memiliki media penyimpanan seperti video home system (VHS), kaset, atau compact disc untuk dapat menikmati konten di dalamnya. Kini, sepanjang user memiliki akses ke suatu katalog, ia akan dapat menikmati konten yang terdapat dalam katalog tersebut. Mulligan (2018) menyebutnya perubahan pola konsumsi berdasarkan kepemilikan menjadi berdasarkan akses yang dimiliki (Mulligan, 2018). User hanya perlu terhubung dengan suatu katalog streaming untuk menikmati konten yang pilihannya banyak dan disediakan oleh layanan streaming.

Salah satu aplikasi digital audio streaming yang populer di dunia saat ini adalah Spotify. Spotify dapat digunakan pada ponsel pintar bersistem operasi Android maupun iOS, dan dapat digunakan juga pada perangkat komputer (personal computer/PC dan laptop) bersistem operasi Windows maupun MacOS. Spotify diluncurkan pada 2006 di Stockholm, Swedia (Iqbal, 2019). Mengutip Eriksson, Fleischer, Johansson, Snickars, dan Vonderau (2019), keberadaan Spotify pada saat itu menawarkan pola baru dalam konsumsi musik secara khusus dan budaya digital secara umum. Spotify menawarkan 
streaming sebagai cara baru pendengar musik mengonsumsi musik tanpa perlu mengunduh filenya ke perangkat mereka. Hal ini menjadi pendekatan baru yang mendobrak budaya menyimpan file musik ke dalam perangkat seperti yang dilakukan dengan iPod (Eriksson, Fleischer, Johansson, Snickars, \& Vonderau, 2019, p. 51).

Spotify terus tumbuh pesat sejak diluncurkan. Hingga triwulan IV 2018, Spotify mencatat telah memiliki 207 juta pengguna aktif di 78 negara. Dalam periode yang sama, keuntungan yang diperoleh telah mencapai 1.495 miliar euro (Spotify, 2019). Dari segi konten, Spotify telah memiliki 40 juta lagu dalam katalognya (Iqbal, 2019) dan jumlah ini terus tumbuh. Jumlah lagu sebesar itu dalam suatu katalog musik streaming tidak menjamin user dapat menikmati pengalaman mendengarkan musik yang maksimal jika mereka tidak dapat menemukan lagu yang mereka mau, meskipun sebenarnya lagu yang mereka inginkan ada di katalog tersebut. Herbert et al. (2018) berargumen katalog audio yang memiliki banyak konten, seperti milik Spotify, harus didukung sistem navigasi yang baik. Navigasi tersebut misalnya melalui algoritma rekomendasi dan keberadaan playlist (Herbert et al., 2018, p. 6).

Meskipun Spotify adalah sebuah aplikasi digital audio streaming yang menawarkan audio sebagai konten utamanya, user justru tidak dapat menavigasi aplikasi untuk menemukan musik yang diinginkan melalui audio. Sebagai sebuah aplikasi, Spotify dinavigasi melalui aspek-aspek visualnya. Aspek-aspek visual ini - selanjutnya disebut cues - menunjukkan bahwa ada cara menavigasi diri dalam aplikasi untuk menemukan konten yang ingin diakses. Merujuk pada Social Information Processing Theory (SIPT), cues dibedakan menjadi dua jenis. Kedua jenis cues adalah verbal cues dan non-verbal cues (Griffin, Ledbetter, \& Sparks, 2019, p. 118). Secara visual, cues dapat diamati antara lain dari judul lagu, judul album, dan playlist (McKelvey \& Hunt, 2019).

Oleh karena itu, artikel ini ingin menegaskan bahwa aspek visual berupa cues merupakan aspek penting karena menjadi petunjuk utama bagi user untuk menavigasi konten dalam sebuah aplikasi digital audio streaming. Hal ini menjadi penting mengingat peran visual tetap menjadi yang utama dalam sebuah aplikasi mobile, termasuk bagi Spotify. Mengingat bahasan yang dibangun adalah mengenai mobile app, artikel ini membatasi penelitian pada mobile app Spotify yang dapat digunakan di ponsel pintar berbasis Android dan iOS.

Artikel ini mengadaptasi konsep cues pada penelitian Burgers et al. (2016) tentang peluang sebuah aplikasi diunduh dari app market. Penelitan tersebut mengatakan ada dua cue yang menentukan keputusan user mengunduh sebuah aplikasi. Kedua cue tersebut adalah karakteristik desain visual dari ikon aplikasi dan rekomendasi online tentang app itu sendiri (Burgers, Eden, de Jong, \& Buningh, 2016, p. 327). Namun perlu digarisbawahi bahwa penelitian tersebut membuat konsep cues untuk mengamati persaingan antar-app dalam suatu app market untuk diunduh. Konsep cue dari penelitian tersebut diadaptasi dalam artikel ini menjadi cara user menavigasi diri dalam sebuah aplikasi digital audio streaming seperti Spotify untuk menemukan musik yang ingin dengarkan. 
Keberadaan aspek kemudahan navigasi (navigability) adalah satu dari empat affordances yang dituangkan dalam model modality, agency, interactivity, dan navigability (MAIN) oleh Sundar (2008). Model ini pula lah yang dirujuk Burgers, Eden, de Jong, dan Buningh (2016) dalam penelitian mereka. MAIN model menjelaskan bagaimana empat affordances membentuk cues dalam media digital, yang pada akhirnya berhubungan dengan kredibilitas bagi media digital tersebut (Sundar, 2008, p. 78). Artikel ini mengadaptasi navigability dalam model MAIN Sundar yang secara garis besar menyebut tanda dalam suatu teks media dapat bernilai heuristik (berhubungan dengan aktivitas penemuan) saat tanda tersebut diasosiasikan dengan makna tertentu yang merujuk pada konten tertentu. Sundar mencontohkan cara kerja navigability lewat hyperlink pada laman web. Hyperlink pada laman web ditandai dengan warna berbeda, umumnya diberi garis bawah, dan menggunakan kata-kata yang mengajak user untuk mengkliknya. Kumpulan hyperlink pada suatu situs web bisa memunculkan nilai heuristik yaitu membawa user ke laman baru. Semakin terorganisasi dengan baik hyperlinkhyperlink yang ada dan semakin mudah navigasinya, maka situs web tersebut akan semakin kredibel di mata user (Sundar, 2008, p. 88). Kata-kata pada hyperlink merupakan informasi yang dapat dimaknai oleh user secara asosiatif karena kata-kata tersebut akan dikaitkan dengan hal-hal dalam ingatannya (Sundar, 2008, p. 89).

Jika merujuk pada masalah dalam artikel kali ini, cara kerja cues dalam Spotify dapat dijelaskan persis dengan navigability tersebut. Sebagai contoh, salah satu verbal cues dalam aplikasi Spotify adalah judul lagu. Saat membaca judul lagu pada rekomendasi Spotify, user akan merujuk judul lagu tersebut ke ingatannya. User memastikan jika ia pernah mendengar lagu yang direpresentasikan oleh judul lagu tersebut atau belum. Jika sudah, user akan melakukan upaya recall untuk mengingat kembali seperti apa lagu tersebut. User kemudian memutuskan akan mendengarkan lagu itu di Spotify atau tidak. Jika ia ingin mendengarkan lagunya, user akan mengetuk (tap) judul lagu yang muncul tersebut. Sundar mengatakan fitur-fitur navigasi digunakan untuk memediasi user agar dapat menempatkan dirinya di antara konten media, lalu menunjukkan arah yang tepat agar user dapat memaksimalkan pengalaman menggunakan media (Sundar, 2008, p. 89). Mendengarkan lagu sesuai keinginan di aplikasi Spotify adalah salah satu contoh konkretnya.

Penelitian lain oleh MacGregor (2005) menunjukkan ada kaitan antara desain sistem dan kemampuan user membangun model dalam pikirannya dalam menggambarkan cara kerja suatu sistem (Macgregor, 2005, p. 191). Gagasan ini dapat dikembangkan dalam proses user Spotify memilih konten. Lewat cues yang disintesis dalam artikel ini, user Spotify membangun model dalam pikirannya yang dapat menggambarkan cara kerja sistem Spotify. Gambaran mental sebagai pola navigasi ini mendukung pendapat Sundar (2008) tentang makna asosiasi dari teks dalam aplikasi Spotify. Aksi yang dilakukan user seperti mengetuk judul lagu pada laman pencarian akan membuat lagu tersebut diputar oleh aplikasi.

Penelitian-penelitian sebelumnya tentang navigability app telah membahas cues dalam bentuk karakter ikon visual dan rekomendasi online yang berhubungan dengan 
persaingan app untuk diunduh dalam sebuah app market (Burgers et al., 2016), navigasi sebagai satu dari empat affordances yang menentukan kredibilitas suatu media digital (Sundar, 2008), dan navigasi berdasarkan kemampuan user membangun model cara kerja media dalam pikirannya (Macgregor, 2005). Namun, ketiga penelitian tersebut tidak membahas secara detail keberadaan cues dalam suatu app yang spesifik. Terlebih lagi, app tersebut secara spesifik merupakan sebuah digital audio streaming app, dengan karakteristik utamanya berupa konten audio. Maka, artikel yang dikerjakan kali ini akan berkontribusi menunjukkan bahwa sebagai suatu mobile app, elemen visual tetap menjadi yang utama bagi user untuk menavigasi diri mereka di antara jutaan konten musik, dan membantu user menemukan musik yang ingin dengarkan. Dengan menerapkannya pada app Spotify, artikel ini berharap dapat menunjukkan peran verbal dan non-verbal cues secara visual bagi app yang secara spesifik terspesialisasi dalam konten audio.

Dalam artikel tentang cues Spotify kali ini, konsep karakteristik desain visual (Burgers et al., 2016) diadaptasi menggunakan verbal cues dan non-verbal cues dari SIPT. Konsep verbal cues dan non-verbal cues hasil adaptasi tersebut kemudian diperjelas lagi menggunakan konsep dari McKelvey dan Hunt (2019). Dari hasil sintesis, konsep yang muncul untuk verbal cues adalah judul lagu, nama penyanyi, judul album, dan playlist. Sedangkan konsep untuk non-verbal cues adalah artwork yang mendampingi verbal cues. Kedua cues ini lah yang akan digunakan sebagai pedoman navigasi bagi user untuk menemukan musik yang diinginkan di Spotify. Tetapi dalam penelusurannya nanti, artikel ini tidak menutup kemungkinan akan adanya cues atau pedoman navigasi baru yang teridentifikasi.

\section{METODE PENELITIAN}

Untuk mengamati fenomena app Spotify tersebut, artikel ini menggunakan pendekatan kualitatif dengan metode pengumpulan data berupa analisis konten kualitatif dan focus group discussion (FGD). Metode pertama digunakan untuk meneliti unsur-unsur visual yang terdapat pada aplikasi Spotify. Unsur-unsur visual tersebut diterjemahkan menjadi verbal cues yang berkaitan dengan kata-kata dan bahasa seperti judul lagu, nama penyanyi, dan nama playlist. Sementara itu non-verbal cues adalah artwork pada playlist maupun album atau lagu. Secara tekstual, fitur-fitur navigasi dalam aplikasi Spotify seperti Home atau Search dikaitkan dengan verbal dan non-verbal cues untuk melihat desain sistem Spotify dalam navigasi pencarian lagu.

Analisis konten kualitatif berbeda dengan analisis konten kuantitatif. Jika analisis konten kuantitatif memperlakukan teks sebagai kata-kata yang perlu dihitung secara statistik, analisis konten kualitatif secara intensif menganalisis bahasa dalam teks dan membuat kategorisasinya (Weber, 1990 dalam Hsieh dan Shannon, 2005, p. 1278). Analisis konten kualitatif dapat dijelaskan sebagai suatu metode yang penekanannya pada interpretasi subjektif terhadap suatu teks, dan melihatnya sebagai suatu proses sistematis yang membuat kategorisasi, koding, dan berupaya menemukan pola pada teks (Hsieh \& Shannon, 2005, p. 1278). Downe-Wamboldt (1992) mengatakan penelitian yang 
menggunakan analisis konten kualitatif ingin memperoleh pengetahuan dan mendapatkan pemahaman dari suatu fenomena.

Pada analisis konten kualitatif, fokus penelitian terletak pada komunikasi dan bahasa yang digunakan, serta melihat hubungan teks dengan konteksnya (Lindkvist, 1981; Tesch, 1990; Budd, Thorp, dan Donohew, 1967; dan McTavish dan Pirro, 1990 dalam Hsieh dan Shannon, 2005, p. 1278). Teks yang dapat menjadi data dalam analisis konten kualitatif meliputi antara lain bentuk cetak seperti artikel dan buku, bentuk elektronik, maupun verbal. Bahkan analisis konten kualitatif dapat digunakan untuk menganalisis jawaban pertanyaan survei yang bersifat open-ended dan FGD (Kondracki dan Wellman, 2002 dalam Hsieh dan Shannon, 2005, p. 1278).

Metode kedua yang digunakan dalam artikel ini adalah FGD. FGD merupakan cara mendapatkan data mendalam tentang suatu fenomena atau topik penelitian (Morgan, 1997 dalam Rothwell, Anderson, dan Botkin, 2016). Melalui FGD, data yang diperoleh peneliti merupakan hasil pernyataan kolektif informan dari hasil klarifikasi dan identifikasi bersama. Data hasil pernyataan kolektif yang seperti ini menjadi kelebihan FGD dibandingkan wawancara mendalam secara empat mata (Kitzinger, 1995 dalam Tausch dan Menold, 2016). Carey (1994), Stewart, Shamdasani, dan Rook (2007) mendukung pendapat tersebut dengan mengatakan pengalaman bersama dan opini yang disuarakan bersama merupakan hasil dinamika FGD dan merupakan kekhasan dari melakukan pengumpulan data dengan cara tersebut (Tausch \& Menold, 2016, p. 1). Sementara itu, Guttman (2007), Cobb (2011), dan Kitzinger (1995) menekankan kualitas data yang diperoleh baik dari wawancara empat mata maupun FGD sangat tergantung dari pengetahuan partisipannya (Rothwell, Anderson, \& Botkin, 2016, p. 734).

Fokus penelitian yang diajukan di artikel ini adalah menunjukkan verbal cues dan nonverbal cues sebagai cara user menavigasi diri dalam aplikasi digital audio streaming untuk menemukan lagu yang diinginkan. Artikel ini juga menekankan bahwa verbal cues dan non-verbal cues merupakan cues yang dapat diidentifikasi secara visual melalui sensor optik manusia. Artikel ini mengidentifikasi verbal cues sebagai segala sesuatu yang berhubungan dengan kata dan bahasa, antara lain judul lagu, nama penyanyi, judul album, dan judul playlist. Sementara, itu non-verbal cues dapat diidentifikasi sebagai segala sesuatu yang tidak berhubungan dengan manusia tapi bisa berhubungan dengan gambar atau tanda-tanda visual lain, misalnya artwork pada album, foto penyanyi, atau artwork pada playlist.

Selain itu, pengamatan awal pada aplikasi mobile Spotify membuat asumsi awal bahwa fitur navigasi yang terdapat dalam aplikasi tersebut antara lain laman Home, laman Search, laman Your Library, laman Playlist, dan laman Now Playing. Upaya navigasi dalam Spotify juga berkaitan erat dengan upaya recall ingatan user. Baik verbal cues maupun non-verbal cues akan dimaknai secara asosiatif oleh user. Hal itu karena user berusaha mengaitkan cues tersebut dengan ingatan mereka, memastikan jika cues tersebut berkaitan dengan salah satu lagu yang pernah mereka dengarkan sebelumnya. 
Karena artikel ini menggunakan metode FGD, maka ada responden yang diikutsertakan dalam proses tersebut. Responden ditentukan lewat purposive sampling seperti dirujuk dari Robson (2011) (Balogun \& John-Akinola, 2015, p. 2413). Wawancara direkam dan dibuat verbatimnya, kemudian dilakukan koding untuk mendapatkan jawaban dari tiap responden serta menemukan kesamaan jawaban yang dapat membentuk pola.

Sampel teks yang dianalisis secara kualitatif berasal dari laman dalam aplikasi Spotify. Kriteria pemilihan laman yang menjadi sampel adalah laman-laman pada aplikasi Spotify yang menggambarkan adanya fitur-fitur utama yang mendukung kemudahan navigasi. Hasil penelusuran menemukan laman-laman yang masuk kriteria adalah Home, Search, Your Library, Now Playing, dan Playlist.

Pengumpulan data tekstual dari aplikasi Spotify untuk mengidentifikasi fitur-fitur utamanya didapatkan dari aplikasi Spotify yang ada pada ponsel pintar berbasis Android, Samsung Galaxy A7 (2018) milik peneliti. Laman-laman tersebut kemudian ditangkap layar (screenshot) untuk dikoding dan diidentifikasi. Koding dan identifikasi yang dilakukan berhubungan dengan elemen cues yang telah dipaparkan sebelumnya. Sebagai catatan, aplikasi Spotify yang ditangkap layar aktif dalam bahasa Inggris.

Di sisi lain, pengumpulan data melalui FGD dilakukan pada 21 Mei 2019 dan melibatkan lima orang partisipan. Secara purposive, kriteria responen adalah pengguna Spotify yang berlangganan Spotify Premium, berumur 17 tahun atau lebih, dan berdomisili di Jakarta. Kelima pastisipan dalam FGD ini adalah AL (24, laki-laki), RR (23, perempuan), RMP (34, laki-laki), AR (23, perempuan), dan FN (27, perempuan). Pertanyaan yang diajukan saat FGD berhubungan dengan aspek visual (verbal dan non-verbal cues) dan pengalaman menggunakan Spotify, eksplorasi pada aplikasi, serta penggunaan fitur-fitur yang ada seperti fitur pencarian (search) dan playlist.

Analisis teks kualitatif dianalisis secara deduktif lewat koding untuk mengonfirmasi keberadaan konsep deduktif berupa cues pada aplikasi Spotify. Teknik analisis ini dimungkinkan lewat directed content analysis. Directed content analysis dilakukan dengan mengidentifikasi konsep-konsep kunci di awal penelitian, dan dibangun lewat teori. Potter dan Levine-Donnerstein (1999) dalam Hsieh dan Shannon (2005) mengatakan konsep-konsep kunci yang diidentifikasi di awal menjadi bagian dari kategori koding (Hsieh \& Shannon, 2005, p. 1281). Secara deduktif, perumusan koding didasari oleh peran teori (Potter \& Levine-Donnerstein, 1999, p. 264). Kedua pendapat tersebut sejalan dengan pendapat Elo et al. (2014) yang mengatakan analisis konten yang baik mampu mendeskripsikan fenomena melalui kategorisasi, suatu konsep, pemetaan, atau membuat model (Elo et al., 2014, p. 1).

Untuk menganalisis FGD, digunakan metode koding yang dihubungkan dengan keberadaan cues. Jawaban partisipan dikaitkan dengan verbal dan non-verbal cues yang telah teridentifikasi sebelumnya. Jawaban partisipan akan menjadi data yang menunjukkan bahwa user berinteraksi dengan cues dalam upaya mereka menavigasi diri dalam aplikasi Spotify. Karena pertanyaan yang diajukan adalah pertanyaan 
semiterstruktur, artikel ini mengasumsikan akan ada jawaban informan yang memunculkan konsep baru. Konsep tersebut dapat digunakan untuk memperkaya pengalaman menggunakan aplikasi digital audio streaming Spotify sekaligus memperkaya variasi cues dalam aplikasi tersebut.

\section{HASIL DAN PEMBAHASAN}

\subsection{Analisis Konten Kualitatif}

Analisis konten kualitatif dimaksudkan untuk menunjukkan dan mengonfirmasi bahwa terdapat cues berupa verbal dan non-verbal cues pada aplikasi Spotify. Secara deskriptif, dapat diamati dengan jelas perbedaan antara verbal dan non-verbal cues dari tampilan aplikasinya. Dari hasil penelusuran konten secara kualitatif ini pula lah, diketahui ada tiga bilah utama untuk menavigasi dan menemukan konten-konten yang terdapat pada aplikasi Spotify. Ketiga bilah tersebut adalah bilah Home yang berada di kiri bawah, bilah Search yang berada di tengah bawah, dan bilah Your Library yang berada di kanan bawah. Secara visual, ketiga bilah utama tersebut tergambar dari Tabel 1 di bawah ini:

Tabel 1. Tiga Bilah Utama Spotify pada Ponsel Pintar

[Sumber: Aplikasi Spotify Mobile, diakses dari akun Spotify milik Maharso]

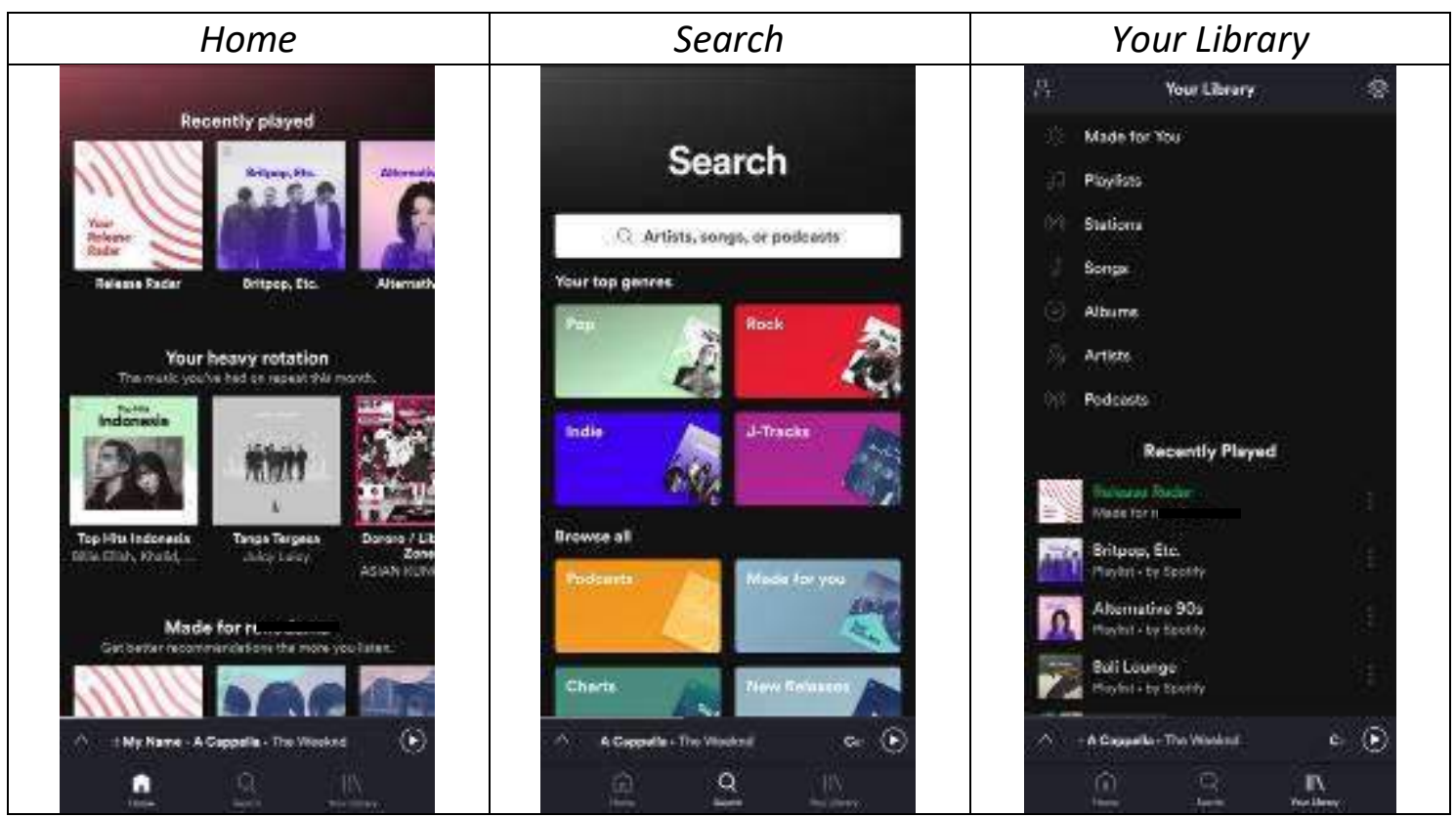

Tampilan dari ketiga bilah utama di atas secara garis besar telah menunjukkan fungsi navigasi yang berbeda satu sama lain, meskipun tidak dipungkiri ada kemiripan dari sisi layout. Non-verbal cue pada ketiga laman di atas menunjukkan dominasi warna latar belakang hitam, bilah berwarna abu-abu, dan warna tulisan putih sebagai identitas aplikasi Spotify. Ketiga laman sama-sama memiliki verbal cues berupa nama-nama (judul lagu, nama playlist, nama penyanyi, nama kategori) dan nonverbal cues (ikon dalam aplikasi, artwork playlist yang berbeda satu sama lain).

Ketiga laman menempatkan bilah utama pada bagian bawah layar. Ukuran ikon bilah yang besar menandakan bahwa Home, Search, dan Your Library benar sebagai cara 
navigasi utama dari Spotify. Secara berurutan dari kiri ke kanan, bilah-bilah tersebut adalah Home, Search, dan Your Library. Ketiga bilah sama-sama direpresentasikan dengan verbal cue (nama bilah) dan non-verbal cue (ikon bilah). Baik posisi maupun urutan ketiga bilah tidak berubah saat laman berpindah. Tetapi, hal yang menjadi pembeda adalah saat suatu laman sedang aktif, warna tulisan dan warna dari satu ikon akan menyala lebih terang dibanding dua ikon lainnya. Hal tersebut turut memberi petunjuk sebagai penanda laman mana yang sedang aktif. Tidak hanya itu, laman yang musik atau playlist-nya sedang aktif akan berubah warna dari putih ke hijau.

Jika mengamati tampilan pada laman Home (tabel kiri), kesan yang muncul adalah laman Home merupakan konten yang terpersonalisasi bagi user Spotify. Tiap user akan memiliki konten terpersonalisasi yang berbeda dengan user lain. Laman Home terbagi ke dalam beberapa kategori besar. Setiap kategori besar memiliki sejumlah playlist yang siap diakses. Kategori-kategori dalam Home: (1) Recently played menunjukkan lagu atau playlist yang baru saja diputar oleh aplikasi; (2) Your heavy rotation menunjukkan musikmusik yang sering diputar ulang dalam sebulan terakhir; (3) Your favorite artists menunjukkan laman penyanyi yang sering diputar atau dicari; (4) Made for .. (username) menunjukkan rekomendasi terpersonalisasi dari Spotify untuk tiap user dan terdiri atas Release Radar, Daily Mix 1-6, Discover Weekly, Your Top Songs 2018, dan Tastebreakers; (5) Keep the vibe going menunjukkan playlist yang sesuai dengan aktivitas terakhir user; (6) Your favorite albums and songs; (7) Popular Artist; (8) Best of artists; (9) Chill; (10) Throwback; (11) More of what your like yang mengompilasi lagu-lagu kesukaan user; (12) Suggested artists; (13) Recommended radio; dan masih banyak lagi. Keteranganketerangan yang disebutkan dalam beberapa contoh kategori di atas disampaikan dalam bahasa Inggris dan menjadi referensi bagi user untuk membuat keputusan membukanya atau tidak.

Bilah yang berada di tengah adalah Search (tabel tengah). Kesan yang muncul dari bilah tersebut adalah user dapat menemukan musik-musik baru. Saat laman Search dibuka, cue yang paling dominan dan menonjol adalah verbal cue berupa tulisan Search. Tulisan Search diiringi non-verbal cue yaitu tulisan dengan warna putih dan ukuran huruf yang relatif lebih besar dari tulisan lain di laman tersebut. Posisi tulisan search juga amat menonjol karena berada di bagian atas laman. Di bawah tulisan Search, ada sebuah persegi panjang dengan latar belakang warna putih. Persegi panjang tersebut berisikan ikon kaca pembesar serta tulisan Artists, songs, or podcasts yang ditulis dengan warna hitam. Informasi visual itu dapat digolongkan sebagai cues. Cues tersebut terdiri atas verbal dan non-verbal cues yang memberi user petunjuk navigasi bahwa kotak itu lah tempat user mencari musik yang diinginkan. Di bawah kotak search, terdapat tulisan Your top genres dan empat bangun persegi panjang yang masing-masing bertuliskan satu genre musik. Keempat persegi panjang tersebut memiliki warna berbeda, tulisan nama genre berbeda, dan artwork berbeda. Nama genre pada tiap persegi panjang ditulis dengan warna putih dan terletak di kiri atas. Setelah empat persegi panjang, muncul tulisan Browse all yang memberi informasi tentang genre lain dalam bilah search. Bilah search ini memiliki total 49 persegi panjang yang masing-masing merepresentasikan sebuah informasi tentang kategori musik. Verbal cues dalam judul 
persegi panjang mewakili informasi yang merepresentasikan kategori musik seperti apa pada setiap persegi panjang. Beberapa contoh genre yang ditulis dalam persegi panjang tersebut adalah Pop, Rock, Jazz, dan Punk. Pengamatan lebih lanjut pada setiap persegi panjang menunjukkan bahwa tidak semuanya memiliki verbal cue yang terkait dengan nama genre musik. Alih-alih, informasi yang dituliskan pada persegi panjang juga menggambarkan suasana seperti Chill dan Dinner, serta menggambarkan aktivitas seperti Workout dan Sleep. Setiap persegi panjang bekerja sebagai cue navigasi yang merepresentasikan jenis musik tertentu sesuai dengan suatu kriteria spesifik (genre musik atau jenis aktivitas). Persegi-persegi panjang tersebut menjadi pintu untuk mengakses pilihan-pilihan playlist. Saat persegi panjang tersebut diketuk, user akan dipindahkan ke laman lain dengan sejumlah pilihan playlist yang sesuai dengan kriteria musik spesifik pilihan user.

Bilah ketiga adalah Your Library (tabel kanan). Bilah ini memiliki variasi verbal cues paling banyak daripada kedua bilah yang lain. Tidak ada perbedaan besar dari sisi non-verbal cues berupa desain layout, dominasi warna latar, warna tulisan, dan peletakan bilah. Tetapi pada bilah ini terdapat dua ikon di pojok kanan dan kiri atas yang tidak memiliki verbal cues. Ikon pada pojok kiri atas menggambarkan manusia dan merujuk ke profil yang dimiliki setiap user Spotify. Mengetuk ikon tersebut akan membawa user ke laman tentang profil user, termasuk di dalamnya laman untuk mengurus berlangganan Spotify. Ikon pada pojok kanan atas menggambarkan roda gigi dan diasosiasikan pada pengaturan aplikasi/setting. Terdapat tulisan Your Library di posisi paling atas dari laman ini untuk menandakan bahwa user sedang berada di laman tersebut. Mengetuk ikon roda gigi akan membawa user ke laman pengaturan untuk mengatur setelan kualitas musik, layanan unduhan musik luring/offline, hingga penyetelan volume musik. Perbedaan terbesar justru ada pada informasi yang terdapat di verbal cues. Terdapat tujuh kategori untuk menavigasi konten dalam bilah tersebut. Ketujuh kategori ini adalah (1) Made for You; (2) Playlists; (3) Stations; (4) Songs; (5) Albums; (6) Artists; dan (7) Podcasts. Selain pilihan tujuh navigasi konten tersebut, ada tanda bertuliskan Recently Played.

Selain tiga bilah utama, terdapat juga dua laman lain yang perlu diamati. Laman pertama adalah Now Playing yang menunjukkan informasi jika satu musik sedang diputar. Laman kedua adalah Playlists. Laman Playlist menjadi penting karena menunjukkan upaya navigasi dalam aplikasi Spotify (Herbert et al., 2018, p. 6) melalui kurasi dan filter konten yang mengikuti suatu aturan kontekstual. Playlist dapat berperan sebagai filter yang dibentuk melalui kurasi (Lobato, 2018, p. 1). Laman Now Playing dan laman Playlists ditunjukkan pada Tabel 2. 
Tabel 2. Laman Now Playing dan Playlists

[Sumber: Aplikasi Spotify Mobile, diakses dari akun Spotify milik Maharso]

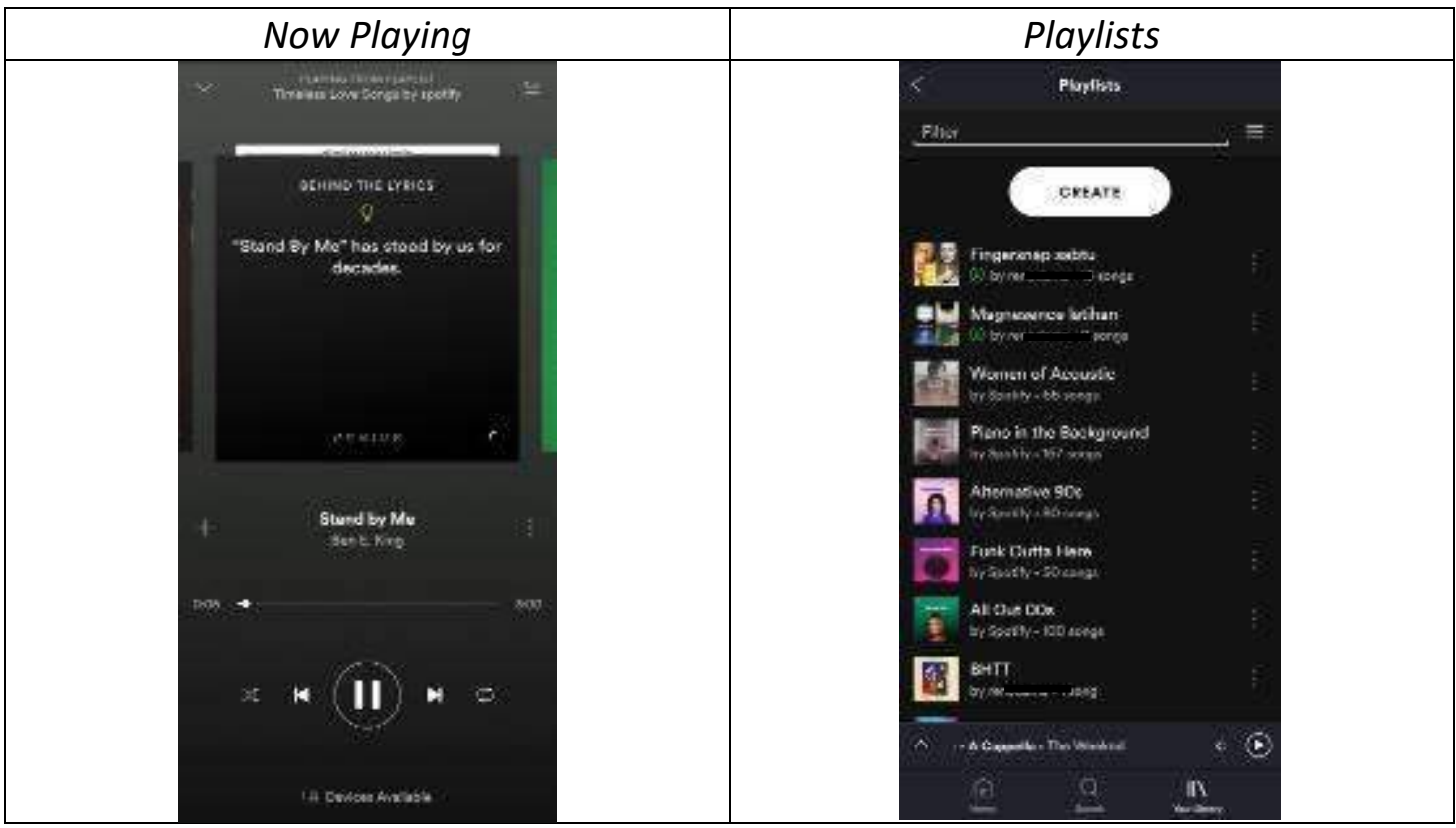

Informasi visual pada laman Now Playing (tabel kiri) dapat dibagi menjadi verbal cues dan non-verbal cues. Verbal cues meliputi judul lagu, nama penyanyi, asal lagu (informasi pada bagian atas tampilan), durasi lagu dalam menit dan detik, dan behind the lyrics yang memiliki cerita di balik lirik lagu tersebut (bagian tengah tampilan). Verbal cues dalam Now Playing berguna untuk mengetahui informasi tentang suatu lagu dan menilai lagu tersebut berdasarkan informasi-informasi yang tersedia. Di sisi lain, non-verbal cues memiliki porsi yang relatif lebih banyak pada laman Now Playing. Pada laman ini, nonverbal cues berupa ikon, diletakkan dengan jelas di satu per tiga laman, dan ukurannya pun besar. Tombol-tombol kendali berupa ikon secara berurutan dari kiri ke kanan adalah: (1) tombol acak lagu/shuffle; (2) tombol repeat; (3) tombol pause/play, terletak di tengah dan berukuran paling besar agar mudah diakses; (4) tombol skip; dan (5) tombol loop. Kelima tombol utama tersebut memiliki skema warna putih. Non-verbal cues lainnya yang berguna untuk kurasi konten adalah minimize pada kiri atas untuk kembali ke laman pilihan lagu yang sebelumnya, dan playlist pada kanan atas untuk melihat urutan lagu yang ditawarkan pada playlist yang sedang diputar saat ini.

Playlist pada bagian kanan memungkinkan user mengubah urutan lagu sesuai keinginan user. Bar durasi juga menunjukkan sudah berapa lama lagu diputar, dilihat dari berapa banyak bagian bar yang menyala dengan warna putih dan ada titik (node) yang menyertainya. Satu hal yang menjadi pembeda laman ini dengan laman lainnya adalah warna latar yang berwarna abu-abu alih-alih hitam. Selain itu, non-verbal cues juga bisa berupa artwork album atau playlist yang menggantikan posisi behind the lyrics. Secara fungsi, non-verbal cues memiliki peran paling penting dalam navigasi konten pada laman ini karena ikon-ikon yang tersedia memberi kekuasaan untuk mengendalikan pemilihan konten, termasuk bar durasi yang dapat disentuh di titik manapun untuk mencari bagian 
lagu yang ingin didengarkan. Dengan kata lain, non-verbal cues memiliki kendali kuat atas konten pada Now Playing.

Laman Playlist (tabel kanan) terdiri atas sejumlah lagu yang disusun menjadi satu dalam sebuah katalog dan diberikan makna kontekstual yang sama, misalnya saja sebagai hasil kurasi yang direkomendasikan secara otomatis oleh sistem (Morris, 2015, p. 447) maupun disusun oleh manusia (Jansson \& Hracs, 2018, p. 1607). Elemen visual yang tertuang dalam non-verbal cues antara lain artwork yang mendampingi suatu playlist dan lingkaran bulat berwarna hijau di bawah judul playlist yang menandakan jika lagulagu dalam playlist disimpan dalam memori aplikasi. Elemen non-verbal cue sekaligus verbal cue yang menonjol pada laman ini adalah tombol besar berbentuk tablet warna putih dengan tulisan CREATE untuk membuat playlist baru. Keberadaan tombol tersebut dapat diartikan bahwa Spotify mendorong user-nya untuk membuat playlist mereka sendiri.

\subsection{FGD Pengalaman User}

Untuk memperkaya data dan melengkapi artikel ini dengan pengalaman user, FGD digunakan. FGD dilakukan pada 21 Mei 2019 dan melibatkan lima orang partisipan sebagai narasumber yang dicatat pendapatnya. Kelima partisipan adalah $A L, R R, R M P$, $A R$, dan FN. Pertanyaan yang sama diajukan kepada masing-masing partisipan, lalu jawaban dari partisipan dirangkum sebagai informasi yang lengkap dari kelima partisipan. Pertanyaan dibatasi pada penggunaan Spotify pada perangkat ponsel pintar masing-masing partisipan, termasuk menggali aspek-aspek visual yang mereka sadari.

Dari hasil FGD, kelima partisipan mengaku seringkali sudah tahu ingin mendengarkan lagu apa sebelum membuka Spotify di ponsel mereka. Dengan begitu, saat mereka membuka Spotify mereka akan mencari lagu tersebut lewat bilah Search. RR menambahkan ada kalanya ia membuka Spotify terlebih dahulu, baru kemudian mencari-cari lagu untuk didengarkan. Hal tersebut dilakukan RR saat sedang fokus mengerjakan tugas dan hanya ingin ditemani musik sebagai latar saja. RR melakukan hal yang sama dengan partisipan lain jika ingin mendengarkan suatu lagu yang spesifik. Jawaban informan dapat direpresentasikan oleh jawaban dari RMP sebagai berikut:

"Lebih milih udah tau lagunya mau apa, baru cari. Habis itu seiring lagunya selesai habis itu silakan berputar dengan lagu-lagu yang lain. Cari dulu. Udah tau mau cari apa, udah dapet, habis itu muter sendiri."

Cara informan menemukan musik yang ingin didengarkan berbeda-beda. AL, RR, RMP, dan FN memilih pergi ke bilah Search setelah membuka aplikasi. Keempat informan ini memasukkan judul lagu pada kotak pencarian, lalu memilih hasil yang relevan dengan musik yang memang mereka cari. RR mengatakan akan memilih lagu yang muncul pada baris paling atas hasil pencarian. AL yakin mencari lagu lewat judul lagu tidak akan membawanya ke hasil pencarian yang salah. Jika judul lagu belum meyakinkan AL bahwa itu memang yang dicari, AL melakukan filter kedua dengan membaca nama penyanyi yang ada tepat di bawah judul sebuah lagu dalam hasil pencarian. Di sisi lain, setelah 
masuk ke aplikasi AR memilih pergi ke laman Playlists dibilah Your Library untuk menemukan playlist yang telah ia buat. Saat masuk ke laman Playlists, AR melakukan pencarian judul playlist. Tetapi AR juga meyakini dirinya tidak akan salah pilih lagu saat melakukan pencarian pada bilah Search karena AR yakin hasil pencarian teratas adalah hasil yang paling akurat.

Kelima informan mengaku mengakses bilah Home dan mendapatkan playlist yang direkomendasikan oleh Spotify. RMP memanfaatkan playlist "Early Noise 2019" dan mendapatkan rekomendasi band baru untuk didengarkan. AR mengakses kategori Heavy Rotations untuk mendengarkan kembali lagu-lagu yang sering didengarkan selama sebulan terakhir. Sedangkan FN memanfaatkan Home untuk menemukan playlist baru yang direkomendasikan Spotify. AL menikmati pilihan lagu yang disajikan pada genre "Mood" yang muncul pada bilah Home-nya. Sementara itu, RR jarang membuka Home kecuali untuk mencari playlist Top 50 saat sedang berkumpul bersama teman-teman untuk menghangatkan suasana. Kelima partisipan mengatakan dalam memilih lagu pada playlist di Home, mereka melihat daftar lagu dan mengamati juduljudul lagu yang ada terlebih dahulu.

Kelima partisipan mengaku sering masuk ke bilah Search dan memanfaatkan fitur-fitur yang tersedia di sana. Pengalaman eksplorasi lagu lebih banyak diperoleh di sana. Hal tersebut dilakukan oleh RMP dan AL. Keduanya mengaku eksplorasi dari bilah Search menawarkan pilihan-pilihan seperti pencarian berdasarkan judul lagu atau nama penyanyi. Bilah Search juga memungkinkan RMP dan AL mengeksplorasi genre-genre musik yang tersedia. RMP yang menyukai genre rock akan mengetuk genre tersebut, lalu memilih playlist yang tersedia di dalam naungan genre seperti "90an" atau "Rock Banget". RMP memilih playlist tersebut berdasarkan pertimbangan telah melihat susunan lagunya, dan itu terlihat dari daftar judul lagu pada playlist. AL yang menyukai musik ber-genre RnB dan pop memilih lagu dalam playlist yang ada di dua genre tersebut. AL akan memilih artis yang disukai lalu membuka laman artis tersebut. AR dan FN sama-sama memulai aktivitas pada bilah Search dengan melihat Recent Searches. FN ingin mendengarkan kembali lagu yang pernah FN cari, dan menemukannya lewat Recent Searches. Sementara itu, AR memanfaatkan Recent Searches hanya untuk mengingat lagu-lagu apa yang pernah dicari. Setelah itu, AR akan menghapus riwayat Recent Searches miliknya. Aktivitas RR di bilah Search terbilang paling konsisten karena setelah masuk ke bilah search, RR akan langsung mengetik judul lagu yang ingin didengarkan di kotak pencarian. Semua partisipan sepakat mencari lagu dimulai dari mengetahui judul lagunya terlebih dahulu, lalu memutuskan mencarinya baik lewat kolom pencarian maupun Recent Searches.

Alasan menggunakan bilah Search bagi RR adalah mempermudah pencarian karena langsung bisa menemukan lagu yang diinginkan dengan cara mencari judul lagu. Sementara itu AL menyenangi bilah Search karena keberadaan Recent History. AR menggunakan bilah search untuk mencari lagu yang diketahui lalu diketik judulnya di kotak pencarian. Setelah menemukan lagu yang dicari, lagu itu akan disimpan ke dalam salah satu playlist yang AR buat. RMP mengaku alasan memanfaatkan bilah Search 
adalah karena mempermudahnya menemukan laman milik band yang pernah didengarkan secara live. Sementara itu FN mengaku bilah Search membantunya menemukan sebuah lagu dengan cepat.

Saat ditanya tentang bilah Your Library, RMP mengaku sebagai pengunjung setia bilah tersebut. RMP melakukannya karena bisa mengakses kembali podcast yang sempat terputus didengarkan karena terpotong oleh kesibukan pekerjaan. RMP menemukan podcast berdasarkan judul yang ditemukan saat menelusuri kategori "Komedi" pada laman podcast. Sementara itu, RR mengunjungi bilah Your Library karena ingin mengakses playlist yang disimpan. RR mendengarkan playlist yang disimpan secara offline, dan itu hanya bisa diakses melalui Your Library. FN mengunjungi bilah Your Library untuk menemukan playlist dan penyanyi. RR akan masuk ke laman Artists untuk mencari nama penyanyi yang ia ingin dengarkan lagu-lagunya dan mencari tahu lagulagu lain dari penyanyi tersebut. AR mengunjungi bilah ini untuk mengakses playlist dan lagu-lagu yang AR merasa tidak yakin ingin menempatkannya di playlist yang mana. AL masuk ke Your Library untuk mengakses laman Liked Songs dan mendengarkan lagu-lagu yang ia pernah beri tanda Like.

Tidak semua informan mengatakan bahwa mereka memperhatikan tampilan konten visual pada laman Now Playing. AL mengatakan ia memperhatikan laman hanya jika lagu yang diputar menampilkan video klip. AR memperhatikan laman tersebut saat muncul lagu baru atau muncul lirik dari layanan pihak ketiga Spotify, yaitu Genius. RMP hanya melihat Now Playing untuk mengetahui judul lagu yang sedang diputar dan belum diketahui. Sementara itu RR dan FN menyatakan tidak mengamati laman Now Playing. Semua informan memanfaatkan tombol skip atau repeat tetapi tidak dari laman Now Playing. Alih-alih, tombol skip, repeat, dan pause/play muncul pada bilah notifikasi ponsel pintar. Bahkan judul lagu, nama penyanyi, dan artwork dapat diinkorporasikan ke dalam bilah notifikasi. Cara ini membantu semua informan untuk mengganti atau mengulang lagu sesuai keinginan mereka.

Tangkapan layar navigasi Spotify dalam bilah notifikasi terlampir dalam gambar di bawah ini. Satu pengecualian dari AL adalah AL melompati (skip) atau mengulangi (repeat) sebuah lagu lewat tombol kendali yang ada di earphone miliknya. Baik bilah notifikasi maupun tombol kendali pada earphone sama-sama menunjukkan bahwa navigasi untuk mengendalikan konten tidak perlu dilakukan dengan masuk ke aplikasinya. 


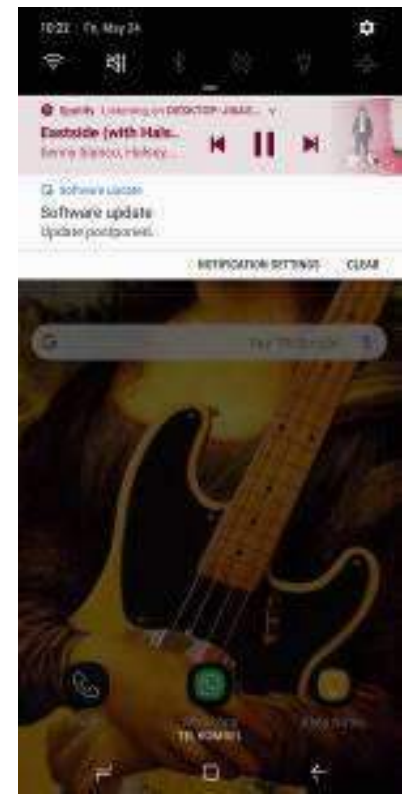

Gambar 1. Bilah navigasi Spotify yang muncul pada bilah notifikasi ponsel pintar

[Sumber: dokumentasi ponsel pintar Maharso]

Saat membicarakan playlist, AR mengaku suka membuka playlist yang dibuat sendiri olehnya. Playlist-playlist tersebut telah disesuaikan menurut mood dan seleranya. AR juga menyusun playlist berdasarkan kegiatannya dan memberi nama playlist-playlist tersebut bukan dengan nama yang umum tetapi disesuaikan dengan kepribadian $A R$ seperti nama playlist "Beast Mode" untuk aktivitas olahgara dan Lex untuk rileks. RMP memiliki enam playlist yang disusun sendiri. Ada playlist yang berhubungan dengan mood dan ada yang berhubungan dengan aktivitas latihan lagu bersama band-nya. Lagulagu yang RMP masukkan dalam playlist merupakan hasil pencarian sendiri dan rekomendasi yang muncul pada laman Now Playing. RR menyusun playlist sendiri dan menyimpan playlist buatan orang lain. Playlist biasanya digunakan RR untuk membantunya rileks saat mengerjakan tugas kuliah. Lagu yang dimasukkan dalam playlist adalah hasil pencarian dari bilah Search. Pencarian bisa dilakukan baik dari judul lagu maupun nama penyanyi. Jika mencari berdasarkan nama penyanyi, RR akan masuk ke laman milik si penyanyi dan memilih lagu berdasarkan rekomendasi lima atau sepuluh lagu terpopuler dari penyanyi tersebut. AL tidak membuat playlist sendiri tetapi mengandalkan playlist yang direkomendasikan Spotify seperti Spotify Chart. AL mempercayai playlist dari Spotify karena menyukai rekomendasi berdasarkan genre sesuai dengan seleranya. Di sisi lain, FN tidak suka membuat playlist tetapi memiliki dua playlist yang disusun sendiri. la memutuskan mengikuti sebuah playlist yang tidak ia buat setelah menelusuri nama artis dan judul lagu. Setelah itu ia bisa membayangkan bahwa lagu dalam playlist tersebut enak didengar.

\subsection{Cues Sebagai Panduan Navigasi User Spotify}

Hasil analisis konten kualitatif menunjukkan bahwa aplikasi mobile Spotify memiliki cues sebagai informasi yang dapat menggambarkan atau merepresentasi konten musik dalam katalog Spotify. Dari penelusuran ini, Spotify memiliki verbal cues dan non-verbal cues. Dalam setiap lamannya, kedua cue saling melengkapi satu sama lain. Sebagai 
contoh, judul lagu merupakan verbal cues. Tetapi non-verbal cues seperti perubahan warna teks judul lagu tersebut dari putih ke hijau memberikan informasi berbeda kepada user. Teks berwarna hijau menunjukkan bahwa lagu dengan judul tersebut sedang diputar. Maka non-verbal cues seperti perbedaan warna juga menentukan dalam memberi tanda posisi user saat ini - lagunya sudah sampai menit berapa, sedang membuka playlist yang mana.

Dari hasil analisis pada bilah Home, Search, dan Your Library, non-verbal cues yang sangat mendominasi adalah warna latar hitam dan warna tulisan putih. Ketiga bilah juga memiliki panel navigasi sama persis yang terletak di bagian bawah laman. Tetapi selain menggunakan non-verbal cues berupa icon, panel navigasi di bagian bawah ditambahkan informasi dalam verbal cues yaitu tulisan Home, Search, dan Your Library. Melihat verbal cues dan non-verbal cues sama-sama muncul pada panel navigasi, dapat disimpulkan bahwa verbal cues dan non-verbal cues sama-sama berperan penting dalam navigasi konten Spotify. Maka, navigability pada aplikasi Spotify sama-sama dipengaruhi kuat oleh verbal cues dan non-verbal cues. Verbal cues yang ditemukan dalam aplikasi ini adalah nama penyanyi, judul lagu, nama genre, nama bilah, nama laman, nama playlist, durasi dalam menit dan detik, hingga nama konten-konten audio lain seperti podcast. Di sisi lain, non-verbal cues meliputi warna hitam pada latar yang menjadi identitas aplikasi ini, artwork album atau playlist, bar durasi lagu, warna putih dan hijau pada judul lagu dan playlist, ikon rumah untuk navigasi bilah Home, kaca pembesar untuk Search, kumpulan buku untuk Your Library, manusia untuk profil, dan roda gigi untuk pengaturan. Karakter warna pada genre juga bertujuan memunculkan mood berbeda.

Dari sisi pengalaman user, diketahui bahwa user sudah mengetahui ingin mendengarkan apa saat membuka Spotify, sehingga kemungkinan yang terjadi ada dua. Pertama, user akan langsung pergi ke bilah search untuk melakukan pencarian judul lagu. Kedua, pergi ke bilah Your Library, kemudian mencari playlist yang memiliki lagu keinginan user. Tetapi bukan berarti user tidak melakukan hal sebaliknya. Ada juga saat-saat user belum mengetahui ingin mendengarkan lagu apa. Jadi, user menyerahkan pilihan menyajikan lagu pada rekomendasi Spotify. Tetapi, user terlebih dahulu membuat batasan genre apa yang ingin mereka dengarkan.

Hasil FGD juga menunjukkan bahwa judul lagu merupakan verbal cues yang utama digunakan untuk menavigasi diri user di antara konten musik yang sangat banyak di Spotify. User menganggap judul lagu cukup kredibel untuk memastikan mereka tidak salah memutar lagu. Kredibilitas itu diperkuat dengan posisi lagu yang berada di urutan teratas dari hasil pencarian. User menganggap mencari lagu lewat bilah pencarian sebagai metode navigasi paling mudah untuk diterapkan. Hal ini karena user dapat langsung memasukkan judul lagu ke kotak pencarian dan menemukan lagu yang diinginkan. Pernyataan ini sejalan dengan cara kerja cues yang diasumsikan di awal. User mengingat sebuah lagu dari judulnya. Untuk menemukan lagu tersebut, user mengandalkan ingatannya (recall) tentang judul lagu tersebut. User kemudian memasukkan judul lagu ke kotak pencarian dan kotak pencarian memunculkan hasil 
pencarian verbal cues berupa judul lagu yang muncul dari hasil pencarian me-recall ingatan user tentang bagian dari lagu yang user tersebut ingat. Merasa yakin jika judul lagu tersebut merujuk pada lagu yang user ingat, user akan memilih memainkan lagu tersebut pada aplikasi Spotify miliknya.

Contoh di atas menjadi bukti bahwa tanda-tanda visual dimaknai oleh user sebagai hal yang memiliki arti tertentu. User dapat mengingat bagian dari suatu lagu saat judul lagu tersebut keluar di hasil pencarian Spotify, atau user dapat mengingat lagu-lagu yang terdapat dalam sebuah album saat artwork album tersebut muncul di rekomendasi dalam bilah Home. Maka, peranan verbal cues dan non-verbal cues sama-sama penting untuk memaksimalkan pengalaman user mendengarkan musik. Verbal dan non-verbal cues juga merujuk pada model mental dalam navigasi di aplikasi Spotify ini. Cues tersebut merujuk pada cara kerja aplikasi yang dimengerti oleh user sebagai suatu sistem dan terdiri atas fitur. Cues yang muncul dipahami sebagai bilah Home, Search, Your Library, Now Playing, Playlist, hingga recommendation. Semua cues bekerja sebagai laman, ikon, tulisan, dan saling terhubung dalam suatu ekosistem aplikasi digital audio streaming dalam perangkat mobile.

\section{KESIMPULAN}

Sebagai kesimpulan, perlu disebutkan kembali bahwa aplikasi digital audio streaming mengandalkan aspek visual untuk digunakan oleh user-nya. Aspek visual ini tertuang dalam verbal cues seperti nama playlist, judul lagu, hingga nama penyanyi; serta nonverbal cues seperti artwork dan ikon-ikon yang muncul di sekujur aplikasi. Cues ini berperan penting sebagai alat navigasi user untuk menemukan konten audio yang diinginkan. Artikel ini mengambil contoh Spotify. Meskipun aplikasi tersebut menawarkan konten audio yang sangat banyak, user tetap membaca judul lagu, melihat artwork, mencari kotak pencarian (search box), dan menelusuri playlist-playlist yang ada. Hal tersebut terjadi karena user Spotify tetap menavigasi diri mereka lewat tampilan visual melalui cues. Cara kerja cues adalah mengasosiasikan tanda-tanda yang muncul dengan ingatan user tentang suatu pengalamannya, dalam hal ini pengalaman mendengarkan musik dengan tanda-tanda yang disajikan oleh Spotify. Cues dalam aplikasi Spotify ini akan mendukung kemudahan navigasi, atau navigability, aplikasi tersebut, sehingga akan semakin memudahkan user menemukan lagu yang diinginkan secara efisien.

Artikel ini dapat membuka peluang penelitian tentang digital audio streaming lebih jauh lagi. Dalam hal penggunaan verbal dan non-verbal cues, penelitian di masa depan dapat mengeksplorasi peran bahasa lokal dengan navigability jenis aplikasi tersebut. Penelitian lain di masa depan juga dapat menggunakan konsep cues dan navigability untuk meneliti aplikasi video streaming atau layanan streaming video-on-demand.

\section{DAFTAR PUSTAKA}

Balogun, M. O., \& John-Akinola, Y. O. (2015). A Qualitative Study of Intimate Partner Violence Among Women in Nigeria. Journal of Interpersonal Violence, 30(14), 2410-2427. 
Burgers, C., Eden, A., de Jong, R., \& Buningh, S. (2016). Rousing reviews and instigative images: The impact of online reviews and visual design characteristics on app downloads. Mobile Media and Communication, 4(3), 327-346.

Elo, S., Kääriäinen, M., Kanste, O., Pölkki, T., Utriainen, K., \& Kyngäs, H. (2014). Qualitative Content Analysis: A Focus on Trustworthiness. Sage Open, (JanuaryMarch 2014), 1-10.

Eriksson, M., Fleischer, R., Johansson, A., Snickars, P., \& Vonderau, P. (2019). Spotify Teardown. London: MIT Press.

Griffin, E., Ledbetter, A., \& Sparks, G. (2019). A First Look at Communication Theory. (E. Griffin, A. Ledbetter, \& G. Sparks, Eds.) (10th ed.). New York: McGraw-Hill Education.

Herbert, D., Lotz, A. D., \& Marshall, L. (2018). Approaching media industries comparatively: A case study of streaming. International Journal of Cultural Studies, 1-18.

Hsieh, H. F., \& Shannon, S. E. (2005). Three approaches to qualitative content analysis. Qualitative Health Research, 15(9), 1277-1288.

Iqbal, M. (2019). Spotify Usage and Revenue Statistics (2019). Retrieved May 22, 2019, from http://www.businessofapps.com/data/spotify-statistics/

Jansson, J., \& Hracs, B. J. (2018). Conceptualizing curation in the age of abundance: The case of recorded music. Environment and Planning A, 50(8), 1602-1625.

Lobato, R. (2018). Rethinking International TV Flows Research in the Age of Netflix. Television and New Media, 19(3), 241-256.

Macgregor, S. K. (2005). Hypermedia Navigation Profiles: Cognitive Characteristics and Information Processing Strategies. Journal of Educational Computing Research, 20(2), 189-206.

McKelvey, F., \& Hunt, R. (2019). Discoverability: Toward a Definition of Content Discovery Through Platforms. Social Media + Society, 5(1), 205630511881918.

Morris, J. W. (2015). Curation by code: Infomediaries and the data mining of taste. European Journal of Cultural Studies, 18(4-5), 446-463.

Mulligan, M. (2018). From Ownership to Access. Retrieved March 26, 2019, from http://www.midiaresearch.com/blog/from-ownership-to-access/

Potter, W. J., \& Levine-Donnerstein, D. (1999). Rethinking Validity and Reliability in Content Analysis.

Rothwell, E., Anderson, R., \& Botkin, J. R. (2016). Deliberative Discussion Focus Groups. Qualitative Health Research, 26(6), 734-740.

Spotify. (2019). Shareholder Letter Q4 2018, 1-13.

Straubhaar, J., LaRose, R., \& Davenport, L. (2012). Media Now: Understanding Media, Culture, and Technology(2011)-1. Michael Rosenberg.

Sundar, S. S. (2008). The MAIN model: A heuristic approach to understanding technology effects on credibility. Digital Media, Youth, and Credibility, 73-100.

Tausch, A. P., \& Menold, N. (2016). Methodological Aspects of Focus Groups in Health Research: Results of Qualitative Interviews With Focus Group Moderators. Global Qualitative Nursing Research, 3. 